\title{
Review of the Literature on Current Changes in the Timing of Pubertal Development and the Incomplete Forms of Early Puberty
}

\author{
Giovanni Farello ${ }^{1 *}$, Carla Altieri ${ }^{1}$, Maristella Cutini ${ }^{1}$, Gabriella Pozzobon ${ }^{2}$ and \\ Alberto Verrotti ${ }^{3}$
}

${ }^{1}$ Pediatric Unit, Department of Life Health and Environmental Sciences, University of L'Aquila, L'Aquila, Italy, ${ }^{2}$ Department of Pediatric, IRCCS San Raffaele Hospital, Milan, Italy, ${ }^{3}$ Pediatric Unit, Department of Biotechnology and Applied Sciences,

University of L'Aquila, Aquila, Italy

OPEN ACCESS

Edited by:

Rodolfo A. Rey,

Center for Endocrinology Research

"Dr. César Bergadá", Argentina

Reviewed by:

Lourdez Ibanez,

Hospital Sant Joan de Déu Barcelona,

Spain

George Paltoglou, National and Kapodistrian University of Athens Medical School, Greece

*Correspondence:

Giovanni Farello

giovanni.farello@cc.univaq.it

Specialty section:

This article was submitted to

Pediatric Endocrinology,

a section of the journal

Frontiers in Pediatrics

Received: 06 February 2019

Accepted: 29 March 2019

Published: 08 May 2019

Citation:

Farello G, Altieri C, Cutini M

Pozzobon G and Verrotti A (2019) Review of the Literature on Current Changes in the Timing of Pubertal Development and the Incomplete Forms of Early Puberty.

Front. Pediatr. 7:147.

doi: 10.3389/fped.2019.00147
Puberty is a sensitive period of life characterized by the appearance of secondary sex characteristics which leads to a complete sexual maturation. It physiologically starts between the age of 8 and 13 years in girls and 9 and 14 years in boys. In the last two decades, several studies have showed that start of puberty has moved up to younger ages by 12-18 months, and some of the hypotheses trying to explain this change include the role of nutritional status and obesity and the influence of extrinsic factors such as exposure to endocrine-disrupting chemicals (EDCs), as well. The hypothalamic-hypophysis-gonadal axis develops during embryogenesis, and except for a period of activation immediately after birth, remains suppressed until the onset of pubertal development. At the beginning of puberty, the pulse generator is reactivated, probably due to progressive stimulatory influences on $\mathrm{GnRH}$ neurons from glial signals and neurotrasmitters. Kisspeptin and its receptor play a fundamental role in this phase. Premature Pubarche/Adrenarche, Premature Thelarche, and Premature Menarche are incomplete forms of precocious pubertal development that have their origin in endocrine mechanisms that only recently have started to be understood. It is important to distinguish these forms from the complete ones in order to reassure patients and parents about the non-evolution of pubertal progression and avoid non-useful treatments with analogous LHRH.

Keywords: puberty, pubarche, telarche, anticipation, development

\section{INTRODUCTION}

Puberty is a sensitive period of life characterized by the appearance and gradual development of secondary sex characteristics which leads to complete sexual maturation and reproductive ability (1).

Puberty is not a single event but the completion of a series of maturational steps starting in the uterus and proceeding during the neonatal period; within the first few months of life, the human infant experiences a transient activation of the hypothalamus-pituitary-gonadal axis, $(2,3)$ a process that has been described as "mini-puberty." (4) Subsequently, the hypothalamus-pituitary-gonadal axis is inactivated until the beginning of pubertal maturation (5). It physiologically starts between the ages of 8 and 13 years in girls and 9 and 14 years in boys. (6). 
Familiar or genetic hereditariness and neuroendocrine factors are some of the determinants of the onset of puberty, which is also influenced by general health, nutrition, exercise and environmental chemicals (7-9).

The completion of puberty is determined by the re-activation of the hypothalamus-pituitary-gonad axis (10) and controlled by neuroendocrine and metabolic factors $(11,12)$.

The secretion of $\mathrm{GnRH}$ is controlled by kisspeptin and its receptor kiss-R1 and is adjusted by neurokinin B and its receptor, whose stimulatory effect increases during puberty, and dynorphin and its receptor, whose inhibitory effect is blocked, resulting in increased GnRH secretion. It has been demonstrated that inactivating mutation in the Kiss-1 or TACR3 genes can result in the absence of puberty (13).

Furthermore, the GnRH pulse source is under excitatory and inhibitory control, so at the onset of puberty the excitatory signal increases while the inhibitory one decreases (14).

The major neurotransmitter responsible for inhibition of $\mathrm{GnRH}$ secretion during childhood is gamma amino butyric acid (GABA) while glutamate, neuropeptide Y, endorphins, opioids and melatonin are responsible for activating the $\mathrm{GnRH}$ pulse generator and consequently setting up the timing of puberty.

In conclusion, the increased frequency and range of $\mathrm{GnRH}$ secretion, along with the increase in excitatory input of kisspeptin through KNDy neurons and glutamate and the decrease in inhibitory signal from GABA neurons, marks the beginning of puberty (5).

Recent studies demonstrated that a switch in the expression patterns of micro-RNAs, which are short non-coding RNAs responsible for silencing gene expression post-transcriptionally, can involve infantile GnRH neurons inverting the balance between inductive and repressive signals, causing an increase in hypothalamic GnRH expression and leading to the start of puberty (15).

Metabolic control is another important factor which influences the onset of puberty, particularly in girls; in fact, important information about the nutritional status and energy reserves are sent to the GnRH neurons $(16,17)$.

During the peripubertal period there is a change in body composition and sensitivity to insulin, in fact a higher body fat content leads to an earlier pubertal maturation, and early puberty is in turn associated with a higher risk of obesity later in life (18).

On the other hand, puberty is also connected to a decrease in insulin sensitivity (19).

Central adiposity is also associated with decreased insulin sensitivity in women (20), so Hillman et al. tried to evaluate the role of adiposity in the association between early puberty and the changes in insulin sensitivity in school-aged girls, finding that central adiposity is responsible for the majority (more than $75 \%$ ) of the changes in insulin resistance during early puberty and showing that pubertal maturation is characterized by more than a simple change in secondary sexual characteristics. It is still unclear what the connection between early puberty and obesity in girls is, but some hypotheses support a mismatch between less prenatal weight gain and more postnatal weight gain as a key factor in early pubertal development $(21,22)$.
In the last two decades, different studies have shown that the start of puberty has moved up in younger ages by $12-18$ months (23) and some of the hypotheses conveyed to explain this change include the role of nutritional status and growth but also the influence of extrinsic factors such as the exposure to the endocrine-disrupting chemicals (EDCs) (24). EDCs cause hypomethylation, and potentially should be able to modify the pubertal process and/or the ability of individuals to cope with the environment (25-27). This class of chemicals is capable of interfering with steroid hormone activity, particularly estrogens and antiandrogens as demonstrated in animal models (28) and seems also to be linked to the shift in puberty timing (29).

Variations in the timing of pubertal development are inheritable. This has been demonstrated in the studies on homozygous twins compared to dizygotic twins $(30,31)$. The knowledge of the underlying mechanisms, including genes that explain variance, is still unclear. Recently, some rare genetic causes of early puberty have been reported and three genes have been identified in the pathogenesis of central precocious puberty: KISS1 (32) encoding kisspeptin, its KISS1R receptor (33) and MKRN3, a gene deemed to act as a hypothalamic repressor on the gonadal axis.

Perry et al. (34) studied 182,416 women from 57 studies, and the authors found 123 signals at 106 genomic loci associated with age at menarche. The genes in the identified loci included those related to the production of $\mathrm{GnRH}$, development and function of the pituitary, bioactivity of hormones, energy homeostasis, growth, and potential peripheral feedback of sex steroids. Some genetic loci identified as influencing pubertal timing had previously been identified as having an impact on BMI, infant growth and adult height $(35,36)$. The 123 SNPs identified by Perry et al. (37) altogether account for only about $2.7 \%$ of menarche age variance, indicating the involvement of multiple genes. Future studies should include interactions with endocrine disruptors that could alter gene expression through epigenetic mechanisms (38)

\section{PROGRESSION OF NORMAL PUBERTY}

The Tanner scale, also known as the Sexual Maturity Rating (SMR) is an objective classification scale used to document and track the development of secondary sexual characteristics in children during puberty.

In females, the normal start of puberty ranges from 8 to 13 years of age, and it is marked by the development of breast buds under the areola; this step is also called thelarche and represents the Tanner Stage B2. In the sequence of events, the thelarche is followed by pubic and axillary hair growth, known as pubarche; in the meantime, growth velocity starts to increase between stage 2 and 3, reaching a peak in stage 4, when the menarche may appear.

In males, the beginning of puberty ranges from 9 to 14 years of age and is marked by a testicular volume equal or $>4 \mathrm{ml}$, representing a Tanner Stage G2. The sequence of events in boys is characterized by the growth of pubic hair and growth of the penis, which follows the enlargement of the testis, and during Tanner 
stage 3 they reach peak growth velocity, usually 2 years later than girls $(39,40)$.

\section{DISORDERS OF PUBERTY}

Over the past centuries, a change in the timing of normal puberty has been demonstrated, with a drastic decline of the age of menarche from 17 years in the early nineteenth century to 13 years in the mid-twentieth century (41). Additionally, the age at the start of breast development seems to be reducing in the last two decades with an average age of the onset of breast development, switching from $\sim 11$ years old before the 1980s to the age of 10 years old between 1988 and 1994 (42). The prevalence of PP in girls appears to be about 10 times higher than boys, showing a prevalence in Denmark of $0.2 \%$ in girls vs. $<0.05 \%$ in boys (43).

Otherwise, the secular trend for precocious puberty in the general population is accompanied by an increase in the prevalence and incidence of PP in girls (44).

Some recent American studies have shown unexpectedly early breast development in girls (45), leading Aksglaede et al. to collect new European data to study the timing of puberty by the clinical evaluation of breast development in a cohort of more than 2,000 schoolgirls around Copenhagen and to search for secular trends in the onset of puberty over a 15 -year period. What they found out was a decrease in the average age from which glandular breast tissue could be palpated, shifting from 10.9 to 9.9 years among the younger girls living in the same geographical area of the oldest ones. Unusually, they discovered that the early breast development was not connected with a higher level of reproductive hormones, probably suggesting gonadotropinindependent estrogenic actions on the breast instead of an early activation of the pituitary-gonad axis (24). After the evidence of a possible breast development before 8 years of age in American girls, some doubts about the reliability of previous standards have been instilled; a secular shift in age of the start of female puberty has been observed while the age of menarche has changed little over the years. The connection between early puberty and obesity remains controversial while there is partial evidence that an early onset of puberty could be related to hyperinsulinemia and insulin resistance (46).

\section{CENTRAL PRECOCIOUS PUBERTY}

The estimated incidence of precocious puberty is between $1 / 5,000$ and $1 / 10,000(47)$.

The definition of precocious puberty (PP) in girls is the development of secondary sexual characteristics before the age of 8 . The onset of puberty before this age is considered pathological. Because of the obvious anticipation in the age of onset of puberty in some studies, researchers have suggested that age 7 years in girls should be used as a threshold for the classification of precocious puberty (48). Other investigators have subsequently concluded that signs of puberty in girls aged 6-8 years cannot be considered normal or benign as this might lead to underdiagnosed endocrine disorders, so
TABLE 1 | Clinical and laboratory evidence of precocious puberty.

Development of the breast buds (Tanner B2 or more) in girls before the age of 8 or the enlargement of the testis over $4 \mathrm{ml}$ in boys before the age of 9 ;

Increased in the growth velocity;

Advanced skeletol maturation;

Enlargement of the size of the ovaries and uterus at the ultrasound examination;

Increased in the basal LH levels and after $\mathrm{GnRH}$ stimulation.

Modified from Sultan et al. (5)

the appropriate threshold for assessment has returned to the previously recommended parameters (49).

Central precocious puberty is caused by early maturation of the hypothalamus-pituitary-gonadal axis and the sexual characteristics are appropriate for the patient's sex (isosexual). The clinical and laboratory evidence of central precocious puberty are reported in Table 1. Central precocious puberty can originate from neurological disorders such as tumors, trauma, or malformations. When there are no detectable CNS lesions, central precocious puberty is defined as idiopathic. These cases might have a genetic, metabolic, or environmental component, or a combination of these factors.

Additionally, peripherical production of sex steroids results in gonadotropin-independent precocious puberty. In this form of puberty, sex hormones are usually derived from the gonads or adrenal glands, or from exogenous sources (50).

\section{INCOMPLETE FORMS OF PRECOCIOUS PUBERTY}

In addition to the complete forms of precocious puberty, incomplete forms of precocious and early puberty are present and require a careful, and often difficult, evaluation in order to be able to decide correctly:

- the appropriate investigations;

- the need for a specialist referral;

- the management of treatment.

\section{PREMATURE PUBARCHE/ADRENARCHE}

Premature pubarche is a form of incomplete puberty characterized by the presence of pubic hair in girls under 8 years of age and in boys under 9 years of age (51). The functional and morphological changes in the adrenal gland cause an elevation in adrenal androgen precursors causing the clinical manifestation of pubarche/adrenarche. DHA plasma level starts to increase at the age of 6 , causing adrenarche (52). With an incidence of $3 \%$, this form of puberty seems to be particularly frequent in the Mediterranean area (11). Additionally, $10-20 \%$ of the cases of premature pubarche are associated with insulin-resistance in obese girls (53). Some of the other clinical features are development of axillary hair, acne, oily skin and hair, and adult body 
odor (5). Skeletal growth and maturation are slightly accelerated, with a good correlation between bone age and chronological age.

It is uncertain if PA is an exaggerated production of DHEA due to early zona reticularis development or an early finding of steroidogenic abnormalities. It is reported that PA increases the risk for PCOS, although it is still not clear if the subjects with exaggerated adrenarche are particularly at risk (54-56).

The causes of premature pubarche/adrenarche have not yet been clarified; one of the theories could be a precocious maturation of the reticularis zone of the adrenal glands, with a peak in the levels of androgens similar to the levels usually reached at the onset of puberty and consequently the growth of pubic hair. In 2006, Vottero et al., tried to search for abnormalities in the androgen receptor (AR) function in both peripheral blood leukocytes and androgen target tissues in girls with premature pubarche and in girls with Tanner stage II; they found out that AR gene methylation was reduced as in girls with Tanner stage II, suggesting an increase in the AR gene activity, therefore leading to a hypersensitivity of the hair follicles to the steroids and to the premature development of pubic hair (57).

The diagnosis is based on the exclusion of other causes such as Precocious Puberty and Non-Classical congenital adrenal hyperplasia (NC-CAH) or a rare virilizing adrenal tumor.

Laboratory assessment for differential diagnosis will measure DHEA, DHEAS, and androstenedione, whose levels may be increased for age in patients with precocious pubarche or similar to the levels normally found in children with Tanner stage II (58); basal serum 17-OH progesterone which may be under $1 \mathrm{ng} / \mathrm{ml}$, followed by an ACTH stimulation test if the $17-\mathrm{OH}$ progesterone is higher than $1 \mathrm{ng} / \mathrm{ml}$.

Basal serum FSH and LH levels after the GnRH stimulation test may be prepubertal, with the left hand and wrist $\mathrm{x}$-ray showing a bone age similar to the biological age (5).

The outcome for girls with premature pubarche is not always positive because the $40 \%$ could present a functional hyperandrogenism during adolescence, and these girls have a higher risk to develop a hyperinsulinemia (59). Therefore, a small group of patients with premature pubarche is associated with smallness for gestational age (SGA) (60).

Premature adrenarche is not the exact equivalent for premature pubarche; in fact, it has been recently defined as a condition characterized by an increase in the adrenal androgen levels for the age and sex-specific range associated with an increase in androgen action such as oily hair and skin and adult-type body odor before 8 years of age in girls and 9 years of age in boys (61). Several studies in the past few years have shown an association between this premature androgen excess with low birth weight, metabolic syndrome in children and poly-cystic ovary syndrome (PCOS), suggesting that a prenatal condition such as low birth weight could be followed by excessive weight gain during childhood, which could lead to a pattern of events culminating with metabolic complications and consequently to premature adrenarche, metabolic syndrome and $\operatorname{PCOS}(21,55)$.

\section{PREMATURE THELARCHE}

Premature thelarche is defined as unilateral or bilateral isolated breast development without the development of other sexual characteristics before 8 years of age without the appearance of pubic hair (1). Skeletal maturation is linear, with a good correlation between bone and biological age. In $80 \%$ of girls it is possible to find a breast volume between B2 and B3, the breast is often tender, and the palpation can be painful (5).

Some of the possible causes of premature thelarche include increased FSH (but not LH) secretion, excessive dietary intake of estrogens such as phytoestrogens and increased breast sensitivity to circulating estrogens (62), obesity and the role of endocrinedisrupting chemicals (EDCs) such as polybrominated diphenyl ethers (PBDEs), which can cause premature thelarche when it reaches high serum concentrations (63). Crofton et al. tried to test whether premature thelarche is associated with increased FSH-driven follicular development; they measured inhibin B (whose role is stimulating estradiol synthesis) and FSH in girls with premature thelarche, central precocious puberty and normal pubertal controls matched for ages and they found that patients with precocious thelarche had inhibin B and FSH levels much higher than their age-matched controls and similar to the levels found in girls with precocious puberty, providing evidence that precocious thelarche is associated with increased follicular development (64). Laboratory assessment shows increased estrogens levels, increased basal serum FSH levels and, after stimulation with GnRH, nocturnal pulsatility, prepubertal basal serum LH levels and after stimulation with $\mathrm{GnRH}$, possible signs of ovarian follicular development and prepubertal size of the uterus (65). Sometimes precocious thelarche can appear before the age of 2 and, after a variable interval of time, it usually completely regresses; in fact, the more precocious the presentation of thelarche is, the more frequent its regression would be (66). On the contrary, when precocious thelarche appears after the age of 2, especially if there has been more breast development, there will not be a complete regression and, furthermore some of the patients may progress to central precocious puberty (67).

\section{PREMATURE MENARCHE}

Premature menarche is defined as menstrual-like vaginal bleeding in girls under the age of 9 without the presence of other signs of pubertal development. The differential diagnosis of unexpected vaginal bleeding includes ovarian cysts, infections or tumors of the genital tract, foreign bodies, trauma, sexual abuse, McCune-Albright syndrome or central precocious puberty (68)

It is a rare condition in prepubertal girls which can appear once or be recurring. It usually resolves after 1 or 2 years and is followed by a normal onset of puberty (69). The main cause of this condition is still unknown, but it seems to be associated with a hypersensitivity of the endometrium to very low levels of estrogens, but it does seem to be related to increased gonadotrophins or estradiol levels. Ultrasound examination conducted on these patients also showed a normal prepubertal state of uterine maturation (70). 


\section{EARLY PUBERTY}

Early puberty is defined by the presence of clinical and auxological signs of pubertal development between the age of 8 and 10 years (71), or between the age of 7.5 and 8.5 years (72) or between the age of 8 and 9 years (73). Some authors found that a relatively early start of puberty may be compensated by a longer duration of pubertal development (74). The mechanism behind early pubertal development has not been clarified yet (75), but some studies have shown an association between restricted prenatal growth and early puberty as a result of a permanent resetting of the endocrine axis (5). This condition may also be related to the secular trend in pubertal timing anticipation (11).

\section{CONCLUSIONS}

Although progress has been made in understanding the neuroendocrine mechanisms of puberty development, it is still necessary to clarify the exact mechanisms that underlie it; an increased understanding of puberty regulation will help to improve the treatment of reproductive disorders.

In the last decades we witnessed a stable anticipation of the first steps of pubertal development even though the age of menarche has remained unchanged. Therefore, it is essential to carefully discriminate patients with complete signs of precocity in pubertal development that require appropriate hormone therapies from patients with partial or slow progressive forms in which careful monitoring is acceptable.

\section{REFERENCES}

1. Delemarre-van de Waal HA. Regulation of puberty. Best Pract Res Clin Obstet Gynaecol. (2002) 16:1-12. doi: 10.1053/beem.2001.0176

2. Forest MG, Cathiard AM, Bertrand JA. Evidence of testicular activity in early infancy. J Clin Endocrinol Metab. (1973) 37:148-51

3. Kuiri-Hänninen T, Kallio S, Seuri R, Tyrväinen E, Liakka A, Tapanainen J, et al. Postnatal developmental changes in the pituitary- ovarian axis in preterm and term infant girls. J Clin Endocrinol Metab. (2011) 96:3432-9. doi: 10.1210/jc.2011-1502

4. Kirivanta P, Kuiri-Hänninen T,Saari A, Lamidi M-L, Dunkel L, Sankilampi U. Transient postnatal gonadal activation and growth velocity in infancy. Pediatrics. (2016) 138:e20153561. doi: 10.1542/peds.2015-3561

5. Sultan C, Gaspari S, Maimoun L, Kalfa N, Paris F. Disorders of puberty. Best Pract Res Clin Obstet Gynaecol. (2018) 48:62-89. doi: 10.1016/j.bpobgyn.2017.11.004

6. Rosenfield RL, Lipton RB, Drum ML. Thelarche, pubarche, and menarche attainment in children with normal and elevated body mass index. Pediatrics. (2009) 123:84-8. doi: 10.1542/peds.2008-0146

7. Reinehr $\mathrm{T}$, Roth $\mathrm{CL}$. Is there a causal relationship between obesity and puberty? Lancet Child Adolesc Health. (2019) 3:44-54. doi: 10.1016/S2352-4642(18)30306-7

8. Leka-Emiri S, Chrousos GP, Kanaka-Gantenbein C. 2017 The mystery of puberty initiation: genetics and epigenetics of idiopathic central precocious puberty (ICPP). J Endocrinol Invest. 40:789-802. doi: 10.1007/s40618-017-0627-9

9. Kaplowitz PB, Slora EJ, Wasserman RC, Pedlow SE, HermanGiddens ME. Earlier onset of puberty in girls: relation to increased body mass index and race. Pediatrics. (2001) 108:347-53. doi: 10.1542/peds.108.2.347
This is even more important given the availability of effective hormonal treatments (analog LHRH) able to block the progression of puberty development in cases of true and complete precocity.

For this purpose, it is necessary to be aware of the incomplete and non-progressive forms of precocious puberty that we find, more and more frequently, in clinical practice given the improvement of living conditions, the increase in the incidence of overweight and obesity and the presence of "disruption of chemicals" in the environment and in food, which seems to be able to induce progressive anticipation of the onset of puberty.

A limitation in our review is the impossibility of specifying the exact role of endocrine disruptors in the development of sexual precociousness, because the available studies are still preliminary and do not reach an univocal conclusion. While confirming the presence of inheritance in advances of pubertal development, more large-scale studies are needed to establish with certainty which genes can be involved in the different forms of anticipation of puberty development.

\section{AUTHOR CONTRIBUTIONS}

GF and GP substantial contributions to the conception or design of the work. MC and CA drafting the work or revising it critically for important intellectual content. AV wrote the first draft of the manuscript. All authors contributed to manuscript revision, read and approved the submitted version.

10. Abreu AP, Kaiser UB. Pubertal development and regulation. Lancet Diabetes Endocrinol. (2016) 4:254-64. doi: 10.1016/S2213-8587(15)0 0418-0

11. Walvoord EC. The timing of puberty: is it changing? Does it matter? J Adolesc Health. (2010) 47:433-9. doi: 10.1016/j.jadohealth.2010.05.018

12. Tony M. Plant: neuroendocrine control of the onset of puberty. Front Neuroendocrinol. (2015) 38:73-88. doi: 10.1016/j.yfrne.2015.04.002

13. Topaloglu AK, Tello JA, Kotan LD, Ozbek MN, Yilmaz MB, Erdogan S,et al. Inactivating KISS1 mutation and hypogonadotropic hypogonadism. N Engl J Med. (2012) 366:629-35. doi: 10.1056/NEJMoa1111184

14. Uenoyama Y, Tsukamura H, Maeda KI. KNDy neuron as a gatekeeper of 574 puberty onset. J Obs Gynaecol Res. (2014) 4:1518-26. doi: 10.1111/jog.12398

15. Messina A, Langlet F, Chachlaki K, Roa J, Rasika S, Jouy N, et al. A microRNA switch regulates the rise in hypothalamic $\mathrm{GnRH}$ production before puberty. Nat Neurosci. (2016) 19:835-44. doi: 10.1038/nn.4298

16. Castellano JM, Tena-Sempere M. Metabolic control of female puberty: potential therapeutic targets. Expert Opin Ther Targets. (2016) 20:1181-93. doi: $10.1080 / 14728222.2016 .1212015$

17. Manfredi-Lozano M, Roa J, Ruiz-Pino F, Piet R, Garcia-Galiano D, Pineda R, et al. Defining a novel leptin-melanocortin-kisspeptin pathway involved in the metabolic control of puberty. Mol Metab. (2016) 5:844-57. doi: 10.1016/j.molmet.2016.08.003

18. Kaplowitz PB. Link between body fat and the timing of puberty. Pediatrics. (2008) 121 (Suppl 3):S208-17. doi: 10.1542/peds.2007-1813F

19. Goran MI, Gower BA. Longitudinal study on pubertal insulin resistance. Diabetes. (2001) 50:2444-50. doi: 10.2337/diabetes.50.11.2444

20. Lapidus L, Bengtsson C, Bjorntorp P. The quantitative relationship between "the metabolic syndrome" and abdominal obesity in women. Obes Res. (1994) 2:372-7. doi: 10.1002/j.1550-8528.1994.tb00077.x 
21. de Zegher F, López-Bermejo A, Ibáñez L. Central obesity, faster maturation, and 'PCOS' in Girls. Trends Endocrinol Metab. (2018) 29:815-18. doi: 10.1016/j.tem.2018.09.005

22. Hillman JB, Huang B, Pinney SM, Pinney SM, Biro FM. Early pubertal development and insulin sensitivity among school-aged girls: mediation via adiposity. Pediatr Adolesc Gynecol. (2013) 2651:47-50. doi: 10.1016/j.jpag.2012.09.007

23. Sørensen K, Aksglaede L, Petersen JH, Juul A. Recent changes in pubertal 564 timing in healthy Danish boys: Associations with body mass index. J Clin Endocrinol Metab. (2010) 95:263-70. doi: 10.1210/jc.2009-1478

24. Aksglaede L, Sørensen K, Petersen JH, Skakkebaek NE, Juul A. Recent 567 decline in age at breast development: the Copenhagen Puberty Study. Pediatrics. (2009) 123:e932-9. doi: 10.1542/peds.2008-2491

25. Euling SY, Selevan Sg, Pescovitz OH, Pescovitz Oh, Skakkebaek NE, Skakkebaek NE. Role of environmental factors in the timing of puberty. Pediatrics. (2008) 121 (Suppl 3):S167171. doi: 10.1542/peds.2007-1813C

26. Kempinas Wde G. Environmental factors in dysregulation of puberty timing and progression. Reprod Toxicol. (2014) 44:v-vi. doi: 10.1016/S0890-6238(14)00037-9

27. Harley KG, Rauch SA, Chevrier J, Kogut K, Parra KL, Trujillo C, et al. Association of prenatal and childhood PBDE exposure with timing of puberty in boys and girls. Environ Int. (2017) 100:132-8. doi: 10.1016/j.envint.2017.01.003

28. Goldman JM, Laws SC, Balchak SK, Cooper RL, Kavlock RJ. Endocrinedisrupting chemicals: prepubertal exposures and effects on sexual maturation and thyroid activity in the female rat-a focus on the EDSTAC recommendations. Crit Rev Toxicol. (2000) 30:135-96. doi: 10.1080/10408440091159185

29. Wang RY, Needham LL, Barr DB. Effects of environmental agents on the attainment of puberty: considerations when assessing exposure to environmental chemicals in the National Children's Study. Environ Health Perspect. (2005) 113:1100-7. doi: 10.1289/ehp.7615

30. Kaprio J, Rimpela A, Winter T, Viken RJ, Rimpela M, Rose RJ. Common genetic influences on BMI and age at menarche. Hum Biol. (1995) 67:739-53.

31. Silventoinen K, Haukka J, Dunkel L, Tynelius P, Rasmussen F. Genetics of pubertal timing and its associations with relative weight in childhood and adult height: the Swedish Young Male Twins Study. Pediatrics. (2008) 121:e885-91. doi: 10.1542/peds.2007-1615

32. Silveira LG, Noel SD, Silveira-Neto AP, Abreu AP, Brito VN, Santos MG, et al. Mutations of the KISS1 gene in disorders of puberty. J Clin Endocrinol Metab. (2010) 95:2276-80. doi: 10.1210/jc.2009-2421

33. Teles MG, Bianco SD, Brito VN, Trarbach EB, Kuohung W, Xu S, et al. A GPR54-activating mutation in a patient with central precocious puberty. $N$ Engl J Med. (2008) 358:709-15. doi: 10.1056/NEJMoa073443

34. Perry JR, Day F, Elks CE, Sulem P, Thompson DJ, Ferreira T, et al. Parentof-origin-specific allelic associations among 106 genomic loci for age at menarche. Nature. (2014) 514:92-7. doi: 10.1038/nature13545

35. Cousminer DL, Berry DJ, Timpson NJ, Ang W, Thiering E, Byrne EM, et al. Genomewide association and longitudinal analyses reveal genetic loci linking pubertal height growth, pubertal timing and childhood adiposity. Hum Mol Genet. (2013) 22:2735-47. doi: 10.1093/hmg/ddt104

36. Elks CE, Perry JR, Sulem P, Chasman DI, Franceschini N, He C, et al. Thirty new loci for age at menarche identified by a meta-analysis of genome-wide association studies. Nat Genet. (2010) 42:1077-85. doi: 10.1038/ng.714

37. Perry JR, Day F, Elks CE, Sulem P, Thompson DJ, Ferreira T, et al. Parentof-origin- specific allelic associations among 106 genomic loci for age at menarche. Nature. (2014) 514:92-7. doi: 10.1210/jcem-37-1-148

38. Lomniczi A, Loche A, Castellano JM, Ronnekleiv OK, Bosch M, Kaidar G, et al. Epigenetic control of female puberty. Nat Neurosci. (2013) 16:281-9. doi: $10.1038 / \mathrm{nn} .3319$

39. Emmanuel M, Bokor BR. Tanner Stages. London: StatPearls Publishing (2018).

40. Marshall WA, Tanner JM. Variations in pattern of pubertal changes in girls. Arch Dis Child. (1969) 44:291-303. doi: 10.1136/adc.44.235.291

41. Tanner JM. Trend towards earlier menarche in London, Olso, Copenhagen, the Netherlands and Hungary. Nature. (1973) 243:95-6. doi: $10.1038 / 243095 \mathrm{a} 0$

42. Euling SY, Herman-Giddens ME, Lee PA, Selevan SG, Juul A, Sorensen TI, et al. Examination of US puberty-timing data from 1940 to 1994 for secular trends: panel findings. Pediatrics. (2008) 121:S172-91. doi: 10.1542/peds.2007-1813D

43. Teilmann G, Pedersen CB, Jensen TK, Skakkebaek NE, Juul A: Prevalence and incidence of precocious pubertal development in Denmark: an epidemiologic study based on national registries. Pediatrics. (2005) 116:13238. doi: 10.1542/peds.2005-0012

44. Mogensen SS, Aksglaede L, Mouritsen A, Sorensen K, Main KM, Gideon P, et al. Diagnostic work-up of 449 consecutive girls who were referred to be evaluated for precocious puberty. J Clin Endocrinol Metab. (2011) 96:1393401. doi: 10.1210/jc.2010-2745

45. Sun SS, Schubert CM, Chumlea WC, Roche AF, Kulin HE, Lee PA, et al. National estimates of the timing of sexual maturation and racial differences among US children. Pediatrics. (2002) 110:911-9. doi: 10.1542/peds.110.5.911

46. Slyper AH. The pubertal timing controversy in the USA, and a review of possible causative factors for the advance in timing of onset of puberty. Clin Endocrinol (Oxf). (2006) 65:1-8. doi: 10.1111/j.1365-2265.2006.02539.x

47. Brito VN, Spinola-Castro AM, Kochi C, Kopacek C, Silva PC, GuerraJunior G. Central precocious puberty: revisiting the diagnosis and therapeutic management. Arch Endocrinol Metab. (2016) 60:163-72. doi: 10.1590/2359-3997000000144

48. Kaplowitz PB, Oberfi eld SE,. Reexamination of the age limit for defi ning when puberty is precocious in girls in the United States: implications for evaluation and treatment and the Drug and Therapeutics and Executive Committees of the Lawson Wilkins Pediatric Endocrine Society. Pediatrics. (1999) 104:936-41. doi: 10.1542/peds.104.4.936

49. Midyett LK, Moore WV, Jacobson JD. Are pubertal changes in girls before age 8 benign? Pediatrics. (2003) 111:47-51. doi: 10.1542/peds.111.1.47

50. Pescovitz OH, Comite F, Cassorla F, Dwyer AJ, Poth MA, Sperling MA, et al. True precocious puberty complicating congenital adrenal hyperplasia: treatment with a luteinizing hormone-releasing hormone analog. J Clin Endocrinol Metab. (1984) 58:857-61. doi: 10.1210/jcem-5 8-5-857

51. Utriainen P, Laakso S, Liimatta J, Jaaskelainen J, Voutilainen R. Premature adrenarche-a common condition with variable presentation. Horm Res Paediatr. 2015 83:221-31. doi: 10.1159/000369458

52. Cathro DM. Adrenal cortex and medulla. In: Hubble D, editor Pediatric Endocrinology. Oxford: Blackwell Scientific Publishers (1969), p. 187.

53. Mantyselka A, Jaaskelainen J, Lindi V, Viitasalo A, Tompuri T, Voutilainen $\mathrm{R}$ et al. The presentation of adrenarche is sexually dimorphic and modified by body adiposity. J Clin Endocrinol Metab. (2014) 99:3889-894. doi: 10.1210/jc.2014-2049

54. Ibanez L, Oberfield SE, Witchel S, Auchus RJ, Chang RJ, Codner E, et al. An international consortium update: pathophysiology, diagnosis and treatment of polycystic ovarian syndrome in adolescence. Horm Res Paediatr. (2017) 88:371-95. doi: 10.1159/000479371

55. Idkowiak J, Lavery GG, Dhir V, Barrett TG, Stewart PM, Krone N, et al. Premature adrenarche: novel lessons from early onset androgen excess. Eur J Endocrinol. (2011) 165:189-207. doi: 10.1530/EJE-11-0223

56. Kurtoglu S, Hatipoglu N, Mazicioglu M, Kendirici M, Keskin M, Kondolot M. Insulin resistance in obese children and adolescents: HOMA-IRcut-off levels in the prepubertal and pubertal periods. J Clin Res Pediatr Endocrinol. (2010) 2:100-106. doi: 10.4274/jcrpe.v2i3.100

57. Vottero A, Capelletti M, Giuliodori S, Viani I, Ziveri M, Neri TM, et al. Decreased androgen receptor gene methylation in premature pubarche: a novel pathogenetic mechanism?. J Clin Endocrinol Metabol. (2006) 91:968-72. doi: $10.1210 /$ jc. $2005-2354$

58. Ghizzoni L, Gasco V. Premature Pubarche. Hormone Res Paediatr. (2010) 73:420-2. doi: 10.1159/000308178

59. Ibanez L, Potau N, Zampolli M, Prat N, Virdis R, Vicens-Calvet E, et al. Hyperinsulinemia in postpubertal girls with a history of premature pubarche and functional ovarian hyperandrogenism. J Clin Endocrinol Metab. (1996) 81:1237-43. doi: 10.1210/jcem.81.3.8772605

60. Neville K, Walker J. Precocious pubarche is associated with SGA, prematurity, weight gain, and obesity. Arch Dis Child. (2005) 90:258-61. doi: 10.1136/adc.2004.053959

61. Utriainen P, Jääskeläinen J, Romppanen J, Voutilainen R. Childhood metabolic syndrome and its components in premature adrenarche. J Clin Endocrinol Metabol. (2007) 92:4282-85. doi: 10.1210/jc.2006-2412 
62. Rosenfield RL. Normal and almost normal precocious variations in pubertal development. Premature pubarche and premature thelarche revisited. Hormone Res. (1994) 41:7-13. doi: 10.1159/0001 83950

63. Deodati A, Sallemi A, Maranghi F, Germani D, Puglianiello A, Baldari F, et al. Serum Levels of Polybrominated Diphenyl Ethers in Girls with Premature Thelarche. Horm Res Ped. (2016) 86:233-239. doi: 10.1159/000444586

64. Crofton PM, Evans NEM, Wardhaugh B, Groome NP, Kelnar CJH. Evidence for increased ovarian follicular activity in girls with premature thelarche. Clin Endocrinol. (2005) 62:205-9. doi: 10.1111/j.1365-2265.2004. 02198.x

65. Della Manna T, Setian N, Damiani D, Kuperman H, Dichtchekenian V. Premature thelarche: identification of clinical and laboratory data for the diagnosis of precocious puberty. Rev Hosp Clin Fac Med Sao Paulo. (2002) 57:49-54. doi: 10.1590/S0041-87812002000200001

66. Volta C, Bernasconi S, Cisternino M, Buzi F, Ferzetti A, Street ME et al. Isolated premature thelarche and thelarche variant: clinical and auxological follow-up of 119 girls. J Endocrinol Invest. (1998) 21:180-3.

67. Pasquino AM, Pucarelli I, Passeri F, Segni M, Mancini MA, Municchi G. Progression of premature thelarche to central precocious puberty. J Pediatr. (1995) 126:11-4. doi: 10.1016/S0022-3476(95)70492-2

68. Schwindinger WF, Levine MA. McCune-albright syndrome. Trends Endocr Metabol. (1993) 4:238-42. doi: 10.1016/1043-2760(93)90128-2

69. Nella AA, Kaplowitz PB, Ramnitz MS, Nandagopal R. Benign vaginal bleeding in 24 prepubertal patients: clinical, biochemical and imaging features. J Pediatr Endocrinol Metab. (2014) 27:821-5. doi: 10.1515/jpem-2013-0415

70. Merckx M, Weyers S, Santegoeds R, De Schepper J. Menstrual-like vaginal bleeding in prepubertal girls: an unexplained condition. Facts Views Vis Obgyn. (2011) 3:267-70.
71. Mul D, de Muinck Keizer-Schrama SMPF, Oostdijk W, Drop SLS. Auxological and Biochemical Evaluation of Pubertal Suppression with the GnRH Agonist Leuprolide Acetate in Early and Precocious Puberty. Hormone Res Paediatr. (1999) 51:270-6.

72. Cassio A, Cacciari E, Balsamo A, Bal M and Tassinari D. Randomised trial of LHRH analogue treatment on final height in girls with onset of puberty aged 7.5-8.5 years. Arch Dis Child. (1999) 81:329-32.

73. Lebrethon MC, Bourguignon JP. Management of central isosexual precocity: diagnosis, treat-ment, outcome. Curr Opin Pediatr. (2000) 12:394-9. doi: 10.1097/00008480-200008000-00020

74. Marti-Henneberg C, Vizmanos B. The duration of puberty in girls is related to the timing of its onset. J Pediatr. (1997) 131:618-21. doi: 10.1016/S0022-3476(97)70073-8

75. Den Hond E, Roels HA, Hoppenbrouwers K, Nawrot T, Thijs L, Vandermeulen $\mathrm{C}$, et al. Sexual maturation in relation to polychlorinated aromatic hydrocarbons: Sharpe and Skakkebaek's hypothesis revisited. Environ Health Perspect.(2002) 110:771-6. doi: 10.1289/ehp.02110771

Conflict of Interest Statement: The authors declare that the research was conducted in the absence of any commercial or financial relationships that could be construed as a potential conflict of interest.

Copyright (C) 2019 Farello, Altieri, Cutini, Pozzobon and Verrotti. This is an openaccess article distributed under the terms of the Creative Commons Attribution License (CC BY). The use, distribution or reproduction in other forums is permitted, provided the original author(s) and the copyright owner(s) are credited and that the original publication in this journal is cited, in accordance with accepted academic practice. No use, distribution or reproduction is permitted which does not comply with these terms. 